Vision of Contemplation: Jesuits and Their Rhetoric of Persuasion in Japan

\author{
Author: Aiko Okamoto-MacPhail
}

Source: Engaging Sources: The Tradition and Future of Collecting History in the Society of Jesus (Proceedings of the Symposium held at Boston College, June 11-13, 2019)

Edited by: Cristiano Casalini, Emanuele Colombo, and Seth Meehan

ISBN: 978-1-947617-09-4

Published by: Institute of Jesuit Sources

Originally Published: July 14, 2021

https://doi.org/10.51238/ISJS.2019.22

Provided in Open Access by the Institute for Advanced Jesuit Studies at Boston College.

The Institute of Jesuit Sources, specializes in preserving, maintaining, and expanding for scholars around the world important texts and studies in Jesuit history, spirituality, and pedagogy.

Visit our website at https://jesuitsources.bc.edu 


\title{
Visions of Contemplation: Jesuits and Their Rhetoric of Persuasion in Japan
}

\author{
AIKO OKAMOTO-MACPHAIL
}

When Saint Francis Xavier set sail to India on April 7, 1541, ${ }^{1}$ it was about a year before the first Europeans "discovered" Japan. ${ }^{2}$ Xavier was nominated núncio apostólico (apostolic messenger) of India by Pope Paul III (r.1534-49) a day before his departure. ${ }^{3}$ In Xavier's time, Japan was but an imaginary land recently added to the nautical charts called portolano. ${ }^{4}$ In 1547, when Xavier met a man named Anjirō in Malacca and decided to come to Japan in the following year, ${ }^{5}$ this country situated at the eastern edge of the Eurasian continent started to take shape in European maps and minds. Our theme is how the Society of Jesus bridged the two extremes of the Eurasian continent by carrying the invisible value of Christianity that gives meaning to the visible world, and how they conveyed this value through expressions.

After Xavier came to Japan in 1549 , the progress of the Society can be traced on maps.

\footnotetext{
${ }^{1}$ George Ganss, S.J., "Introduction," in Ignatius of Loyola, The Spiritual Exercises of Saint Ignatius, trans. George E. Ganss, S.J. (St. Louis, MO: Institute of Jesuit Sources, 1992), 1-14.

${ }^{2}$ Historians in Japan often point out that, from the European perspective, Japan was discovered at this point, but for Japanese and for other Asians, the country was long known.

${ }^{3}$ Kishino Hisashi, Xavier to Higashi Ajia (Tokyo: Yoshikawa Kōbunkan, 2015), 5-41. On the geographically fluid extent of India, see 31-32.

${ }^{4}$ Fernão Vaz Dourado, Atlas, reproduced by Visconde de Lagoa (Lisbon: Editora Biblioteca historica de Portugal \& Brasil, 1948 [1571]).

${ }^{5}$ Francis Xavier, S.J., The Letters and Instructions of Francis Xavier, ed. Joseph Costelloe, S.J. (St. Louis, MO: Institute of Jesuit Sources, 1992), 169-80. On Anjirō, see Kishino, Xavier to Higashi Ajia, 246-52.

https://doi.org/10.51238/ISJS.2019.22

(C) Institute of Jesuit Sources, 2021
} 


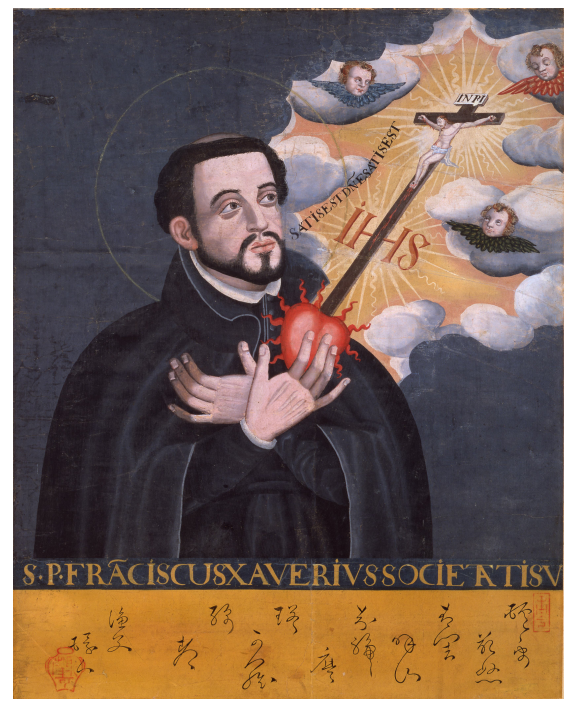

Figure 1. Portrait of Saint Francis Xavier, beginning of the seventeenth century, an anonymous Japanese painter inspired by images of the saint printed in the collection of Xavier's letters published by Orazio Torsellini, S.J. (1545-1599). Color on paper, 61.0 x $48.7 \mathrm{~cm}$. Courtesy of Kobe City Museum, Kobe, Japan. Important Cultural Property.

In Gerard Mercator's map of 1569 that projected the entire globe in a square plane with his method of Mercator projection, Japan looks like a tadpole floating at the edge of the Eurasian continent. A year later, Abraham Ortelius, in his atlas Theatrum orbis terrarum (Theater of the world), added his own version in which Japan resembles, this time, a teardrop, with the main island and adjacent ones streaming southward with the caption: "Island of Japan called Zipangri by Venetian Marco Polo," a land of hearsay from the thirteenth century. ${ }^{6}$ All that changed in 1592 when Ortelius published a new edition of the Theatrum orbis terrarum with the map "Mare Pacificvm" (Pacific Sea) engraved in 1589 in which Japan is presented as follows: "On the other side of China, from Japan and some other neighboring islands, there is a great harvest of Christians, of which every day new settlements are inducted by the faithful labors of the fathers of the Society of Jesus." " Ortelius added another sentence below it: "Island of Japan newly converted into Christianity." 8 The news of the Jesuit mission reached Ortelius between the two editions of his atlas.

\footnotetext{
${ }^{6}$ See the map of "Asia Nova" in Abraham Ortelius, Theatrum orbis terrarum (Antwerp: Aegid. Coppenium Diesth., 1570) with the caption "Japan insula, a M. Paulo Veneto Zipangri dicta."

7 "Mare Pacificum" in Abraham Ortelius, Theatrum orbis terrarium (Antwerp: In officina Plantiniana, 1592): "In China regione, Iapania alijsque insulis vicinis, messis multa Christianorum: quorum indies novæ colonie ducuntur, patribus societatis Iesu fidis operarijs."

8 "Iapan ins. nuper ad Fidem Christianam conversa."
} 


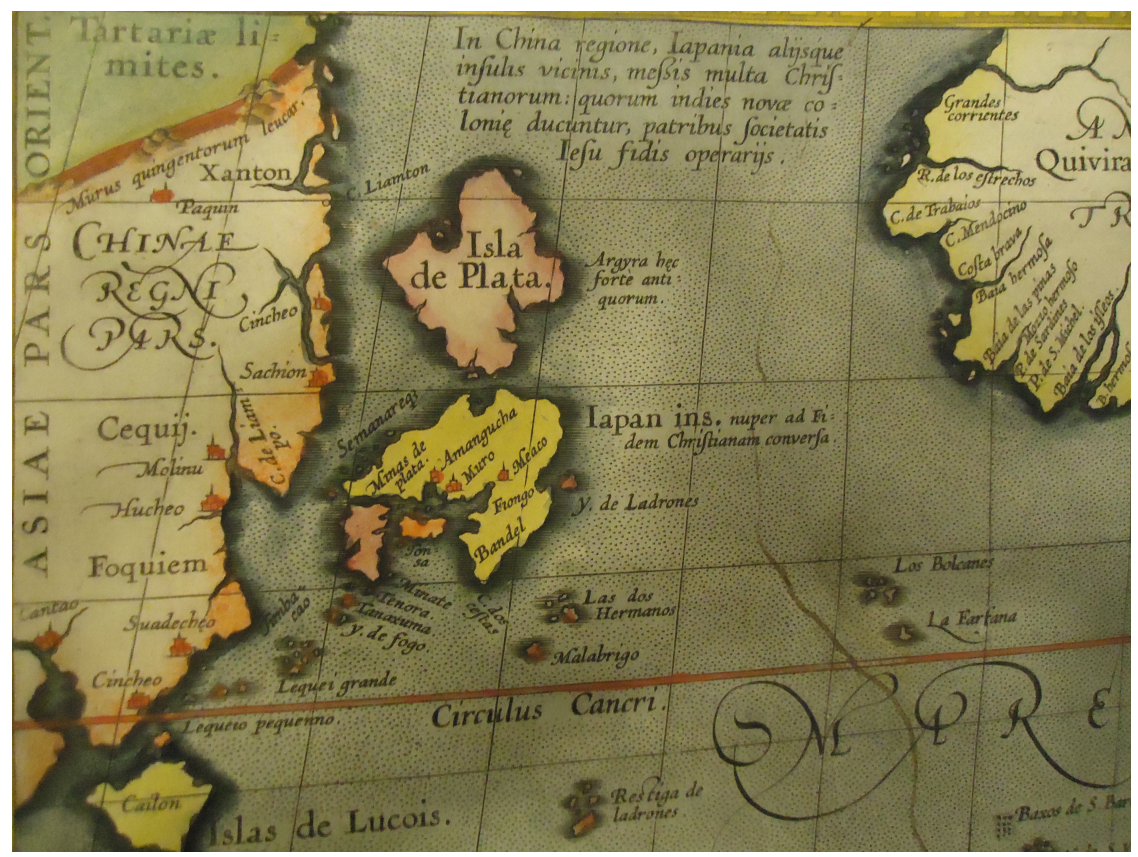

Figure 2. Abraham Ortelius, "Maris Pacifici". Detail. Theatrvm orbis terrarvm, 1592. Color on paper, 34.4 x $49.8 \mathrm{~cm}$. Courtesy Lilly Library, Indiana University, Bloomington, Indiana.

The same year as Xavier left Europe for India, Saint Ignatius of Loyola was completing the Spiritual Exercises. ${ }^{9}$ Loyola wrote the first exercise of the first day in the second week, starting with a prelude called Composition of Place, by envisioning the entire world as seen through the eyes of the three persons of the Holy Family, Mother, Father, and Child. The retreatant should imagine diverse peoples and nations, some smiling and others crying, while speaking different languages, and then zoom in on one time and place, a small corner of the world and a modest house where Mary lives in Nazareth in the province of Galilee. ${ }^{10}$ Loyola wrote his exercises in this dynamic atmosphere of expanding horizons.

The Jesuits faced many difficulties in adapting to an entirely different society such as Japan, and they resorted to rhetorical strategies to bridge the differences. Each world came with its own conventions of expression for its own end of religion, Christianity for the Society and Buddhism in Japan. To bridge them, each party needed to borrow the other's way of expression in order to convey radically new concepts. In what follows, first we will briefly situate Loyola's Spiritual Exercises at the crossroads of the medieval tradition of meditation and the modern philosophy of René Descartes and Blaise Pascal. Second, we will survey the differences and difficulties that the Society encountered in Japan, and in the

\footnotetext{
${ }^{9}$ Ganss, "Introduction," 4.

${ }^{10}$ Ganss, "Introduction," 56-57; Ignatius of Loyola, Exercitia spiritualia, ed. Joseph Calveras, S.J., and Cándido de Dalmases, S.J. (Rome: Institutum Historicum Societatis Iesu, 1969), 224-25.
} 
third part we will study the mission strategy to bridge that gap. In the concluding part, we will put Jesuit rhetoric back into Europe and argue that the ultimate tool of the Society in the arduous course of foreign missions is its understanding of free will.

When in 1637 Descartes published his Discours de la méthode (Discourse on method) in the Protestant Netherlands, Loyola's Spiritual Exercises was nearly one hundred years old. In seventeenth-century France, two thinkers divided the scene of philosophy and meditation. One is the rational Descartes and the other is the mystic Pascal. Today, Descartes is hailed as the father of modern philosophy, while his contemporary Pascal is largely forgotten in philosophy and his texts are read as literature. One century before Descartes and Pascal, Loyola embodies both characteristics in his method of meditation. Descartes, in assigning his Méditations métaphysiques (Metaphysical meditations) as a six-day sequence and in structuring each day progressively up to the concluding meditation, follows Loyola's model of daily meditation over four weeks in the Spiritual Exercises. ${ }^{11}$ At the same time, Loyola anticipated Pascal's tolerance of secular conventions of expression as well as his belief in direct conversation with God, as reflected in Pascal's and his niece's experience of miracles. ${ }^{12}$ The Renaissance source of meditation unified in Loyola splits into the two currents of Descartes and Pascal in the seventeenth century. If Descartes and Pascal are both the offspring of the Renaissance, Loyola comes from the medieval tradition of Devotio moderna (Modern devotion) represented by the Imitatio Christi (Imitation of Christ). Loyola's favorite version was the Imitatio Christi in Jean Gerson's Latin, and it was a classic fixture in the Society's dining room. ${ }^{13}$

Book 1, chapter 1 of the Imitatio ends with the proverb: "The eye is not satisfied with seeing, nor the ear filled with hearing." we can read throughout the Imitatio Christi: "Strive to withdraw your heart from the love of visible things, and direct your affection to things invisible." 15 Starting with the invitation to withdraw from worldly life in book 1, the Imitatio follows a certain spiritual and intellectual progress of meditation, step by step, through books

\footnotetext{
${ }^{11}$ Giulia Belgioioso and Franco A. Meschini, "Philosopher, méditer: L'expérience philosophique chez Descartes," Quaestio 4 (2004): 197-227, lists all the people who found Loyola's influence and other devotional influences in Descartes' meditations, and they explain the common characteristics of Cartesianism and religious meditation that progressively advances from imagination to intellect and then to free will.

${ }^{12}$ Blaise Pascal, Pascal le cour et la raison, ed. Jean-Marc Chatelain (Paris: Bibliothèque Nationale de France, 2016), 156-58; John J. Conley, S.J., The Other Pascals (Notre Dame: University of Notre Dame Press, 2019), 28-29, 82.

${ }^{13}$ Alessandro Valignano, Sumario de las cosas de Japón (1583); Adiciones del Sumario de Japón (1592), ed. José Luis Alvarez-Taladriz (Tokyo: Sophia University, 1954), 636: the Imitatio in Jean Gerson's version was the "Libro predilecto de S. Ignacio de Loyola, que le llamaba afectuosamente su 'Gerçonzito' [...] y obra clásica en los refectorios de la Compañía" (Saint Ignatius of Loyola's favorite book, which he used to call affectionately my "little Gerson" and a classic work in the refectory of the Society).

${ }^{14}$ Thomas à Kempis, The Imitation of Christ, trans. Leo Sherley-Price (New York: Penguin, 1952), 28, from Eccles. 1:8: "Non saturatur oculus visu nec auris impletur auditu."

${ }^{15}$ Kempis, Imitation of Christ. Loyola, Exercitia spiritualia, 222-23 invites his followers to read the Imitatio.
} 
1,2 , and $3 .{ }^{16}$ Book 1 is an exhortation to despise the world, book 2 is the invitation to follow Christ, and book 3 is composed of the dialogue between God and his follower. These three books culminate in book 4 with the communion. This overall sequence of deepening meditation from book 1 to book 4 is identical to Loyola's Spiritual Exercises. ${ }^{17}$ While Loyola endows perception with a positive meaning through Composition of Place, all three thinkers, Loyola, Pascal, and Descartes, aspire to the invisible realm. To do so, however, Pascal and Descartes rely on entirely different working principles that were once unified in Loyola.

In the Spiritual Exercises, the positive meaning of perception is best exemplified in the prelude. In the method called Composition of Place, the five senses are entirely redirected toward the imaginary experience that follows closely Christ's life from nativity to passion. After fully composing the place, the retreatant engages in colloquy. Here, the main use of language is the conversation with the Holy Family. For Loyola, perception is not aimed at the composition of the physical world, but the five senses are entirely devoted to reliving the life and times of Christ. Loyola's perception confirms that Christ is a historical person whom we can see, and yet Loyola can see Christ across time through Composition of Place precisely because Christ is representing something other than what is visible. Through this method, when the retreatant participates in the life of Christ, the purpose of the five senses is not mere perception but compassion for the life of Christ, in that the follower accompanies the passion and dwells in its mystery through the Application of the Senses. ${ }^{18}$ Loyola's senses include the sixth sense of intellect that may or may not guide the retreatant toward a mystical experience. ${ }^{19}$ On this point of mysticism, Loyola converges with Pascal.

For us today, Loyola and Descartes seem like two opposites in that the former belongs to Catholicism and the latter to philosophy. It was also Descartes' contemporary view. That is why Descartes' books were put on the Index in 1663. However, Descartes is not so very distant from the Society of Jesus. René Descartes (1596-1650) studied in the Jesuit college of La Flèche from around 1606 to 1615 and preserved a good enough memory of the Jesuit curriculum of philosophy that he recommended his alma mater to his friend's child. ${ }^{20}$ Alfredo Gatto argues that he wrote his Principia philosophice (Principles of philosophy [1644]) with the hope of this book being adopted as a textbook in Jesuit colleges. ${ }^{21}$ Étienne Gilson goes one step further and speculates that Descartes may have wanted to teach philosophy in his old Jesuit school. ${ }^{22}$ After the publication of his Meditationes de prima

\footnotetext{
${ }^{16}$ Jacques Huijben and Pierre Debongnie, L'auteur ou les auteurs de l'Imitation (Louvain: Publications Universitaires de Louvain, 1957), 13-14.

${ }^{17}$ Ganss, "Endnotes," in Loyola, Spiritual Exercises, 144-45n8.

${ }^{18}$ Loyola, Exercitia spiritualia, 286-87; Ganss, "Introduction," 84.

${ }^{19}$ Ganss, "Endnotes," 163-65, here 165n66.

${ }^{20}$ Alfredo Gatto, "Descartes and the Jesuits," in Jesuit Philosophy on the Eve of Modernity, ed. Cristiano Casalini (Leiden: Brill, 2019), 405-25, here 406, 408.

${ }^{21}$ Gatto, "Descartes and the Jesuits," 410, 421.

${ }^{22}$ Étienne Gilson, La liberté chez Descartes et la théologie (Paris: Alcan, 1913), 438. Descartes was certainly not the kind of philosophy professor the Jesuits had in mind. The Ratio studiorum writes under the rubric of "The Character of the Professor of Philosophy" that "if any professors are
} 
philosophia (Meditations on first philosophy [Paris 1641, Amsterdam 1642, French translation entitled Méditations métaphysiques 1647]), ${ }^{23}$ when the Society's criticism intensified in the person of Pierre Bourdin, ${ }^{24}$ Descartes swiftly moved to remedy the situation. In 1644, Bourdin accepted Descartes' overtures, and the Jesuit theologians received the Principia philosophice offered by Descartes, fresh off the press. ${ }^{25}$

Is this the only affinity of Descartes to the Society of Jesus? Among the books of meditation written by the third Superior General Francis Borgia (151072, in office 1565-72), Cándido de Dalmases, S.J. counts five treatises (treatises 1, $6,11,28$, and 30) structured according to "a very common custom of that era," namely divided by the days of the week, whereas his other way to order the meditations, according to the liturgical calendar of the year, was new in his time. ${ }^{26}$ So Descartes' choice of dividing his Méditations by the days of the week was not new. Moreover, Descartes is sometimes classified as one of the last Scholastics. Back in 1913, Gilson meticulously collated Cartesian concepts with the ones already held by his Scholastic predecessors in his Index scolastico-cartésien (Scholastic-Cartesian index). ${ }^{27}$ To read Descartes as a Catholic thinker was then developed by Henri Gouhier in his work on Descartes' religious thought in $L a$ pensée religieuse de Descartes (Descartes' religious thought) published in 1924 and reedited in 1972. Roger Ariew revived this Catholic reading of Descartes by focusing on the Cartesian interpretation of transubstantiation. Ariew demonstrates that Descartes' position is the standard seventeenth-century Scotist position ${ }^{28}$ while also highlighting the decisive influence of Duns Scotus on Descartes' thought at large. ${ }^{29}$ This observation is the heart of Ariew's claim that, far from severing the ties of philosophy and Scholasticism, Descartes was instead a Scholastic. ${ }^{30}$

Descartes' debt to medieval thought can be seen in his idea of free will. On this point, Descartes converges with Loyola. For Descartes and Loyola, free will is a phone call from God, albeit difficult to hear because, Descartes would say, man is not a high-resolution machine, and nevertheless both Loyola and Descartes invented two different methods to hear it. God is infinite, Descartes explains, so

\footnotetext{
inclined towards innovations or have too free-spirited an intelligence, they definitely ought to be removed from their academic posts." See Claude Pavur, S.J., The Ratio studiorum (St. Louis, MO: Institute of Jesuit Sources, 2005), 13.

${ }^{23}$ Geneviève Rodis-Lewis, "Introduction," in René Descartes, Meditationes de prima philosophia, Méditations métaphysiques, ed. Geneviève Rodis-Lewis (Paris: Vrin, 1978), v-xiv, here ix-xi. Rodis-Lewis criticizes the edition of the Meditationes established by Charles Adam and Paul Tannery in their Euvres de Descartes for numerous inconsistencies, and her edition of 1978 publishes the first French translation by the Duc de Luynes and approved by Descartes. Her edition will be cited as Descartes-Lewis.

${ }^{24}$ Gatto, "Descartes and the Jesuits," 409.

${ }^{25}$ Gilson, La liberté chez Descartes, 325, 327, 330-31.

${ }^{26}$ Cándido de Dalmases, S.J., Francis Borgia (St. Louis, MO: Institute of Jesuit Sources, 1991), 124, 131.

${ }^{27}$ Étienne Gilson, Index scolastico-cartésien (Paris: Alcan, 1913).

${ }^{28}$ Roger Ariew, Descartes among the Scholastics (Leiden: Brill, 2011), 8.

${ }^{29}$ Ariew, Descartes among the Scholastics, 94.

${ }^{30}$ Ariew, Descartes among the Scholastics, 68.
} 
that his grace and knowledge make man feel free when he hears it. ${ }^{31}$ For Descartes, his famous axiom "I think therefore I am" is the absolute departure that does not have any cause that precedes it. ${ }^{32}$ Descartes reasons that God, who contains all objective realities and truth in him, laid down the prime ideas that work as archetypes. ${ }^{33}$ In this third meditation, however, he is moving from innate ideas to objective ideas of science, as in the example that only our rational judgment makes us see the true size of the sun that our natural sight cannot see. ${ }^{34}$ For Descartes, res cogitans or the thing that thinks is the essence of the subject, ${ }^{35}$ and this subject is intricately related to or mixed with the essence of scientific self of res cogitans. Science is useful, Descartes argues, because it makes man keenly aware of his deficient state of knowledge. ${ }^{36}$

What matters for Descartes more than the faculty of knowledge is the faculty of selecting true from false by libre arbitre (by free will, ab arbitrii libertate), ${ }^{37}$ and this latter faculty, namely the faculty of judgment, is the core guide toward Cartesian truth. Free will is more extensive than understanding. ${ }^{38}$ It is one and indivisible ${ }^{39}$ and without extension ${ }^{40}$ and therefore free from the material part of res cogitans. That the thinking subject aspires to perfection is proof enough that this will is an innate attribute of human thought. ${ }^{41}$ In Descartes, however, free will is not oriented toward religious meditation. As we can see from his most famous work, Discours de la méthode, which is written as an introduction to his treatise of physics, Dioptrique, his judgment is exercised mainly in the reconstruction of the created world through science. Descartes is content in his Méditations metaphysiques with the statement that the truth of all science depends on God. ${ }^{42}$

Free will is also defined as a token of creation that God pressed on man as a craftsman who leaves his mark on his work. ${ }^{43}$ Of the six meditations assigned for six days in the Meditationes, the third is devoted to the demonstration of the existence of God. Gilson observes that the Cartesian urge to prove God's existence subscribes to a larger trend in theology that comes from a time before Descartes and continuous to Francisco Suárez, ${ }^{44}$ and the demonstration of God's existence is an expanded application of another theological argument, namely the doctrine of innate ideas. ${ }^{45}$ On innate ideas, a range of different positions were held among

\footnotetext{
${ }^{31}$ Descartes-Lewis, 48.

32 Descartes-Lewis, 49.

${ }^{33}$ Descartes-Lewis, 42.

${ }^{34}$ Descartes-Lewis, 39.

${ }^{35}$ Descartes-Lewis, 76.

${ }^{36}$ Descartes-Lewis, 52.

${ }^{37}$ Descartes-Lewis, 56

${ }^{38}$ Descartes-Lewis, 58.

${ }^{39}$ Descartes-Lewis, 60.

${ }^{40}$ Descartes-Lewis, 76.

${ }^{41}$ Descartes-Lewis, 52.

42 Descartes-Lewis, 69.

${ }^{43}$ Descartes-Lewis, 51.

${ }^{44}$ Étienne Gilson, Études sur le rôle de la pensée médiévale dans la formation du système cartésien (Paris: Vrin, 1967), 36.

${ }^{45}$ Gilson, Études sur le rôle de la pensée médiévale, 29.
} 
theologians that all fell within the margin of orthodoxy before Descartes, ${ }^{46}$ beginning with Thomas Aquinas, who saw a Platonism in the concept of innate ideas, ${ }^{47}$ summarized and refuted them ${ }^{48}$ but could not stop other theologians who kept working for or against innate ideas because the doctrine was continuously reinterpreted by theologians as diverse as Scotus, those in the Commentarii collegii Conimbricensis, and Suárez in his Disputationes metaphysice. ${ }^{49}$ These names, although not all of them, send us to the theology implemented by Jesuit schools. So, the ambition to prove God's existence is not new to Descartes. Even Descartes' concluding idea from the third meditation of innate ideas as an imprint that God left in man as a token of his creation is derived from Marin Mersenne, one of Descartes' most trusted correspondents, whose thoughts Descartes adopted in this respect. ${ }^{50}$ Only, Descartes transferred the ground of demonstration from theology to philosophy. ${ }^{51}$ What is in common in Loyola and Descartes is that both established methods of meditation that are axiomatically applicable to a large public, of which the ultimate aim for both is to decipher the divine voice that speaks through free will to one's mind.

Pascal shows a strong resistance toward Cartesian rationalism. For Pascal, Cartesian hyperbolic doubt is ridiculous, ${ }^{52}$ and he does not agree with either Cartesian or Jesuit step-by-step progress in meditation. In light of the two extremes of the void and the infinite, Pascal argues that all finitude looks identical. ${ }^{53}$ For Pascal, the Cartesian rational and scientific demonstration of God's existence in the Meditationes becomes $L$ 'art de persuader (The art of persuading), in the manner of Michel de Montaigne's L'art de conférer (Art of conferring). Cartesian doubt becomes a milder skepticism that always takes account of the two sides to each argument, and rational demonstration becomes an art of literary rhetoric. In Pascal, what Descartes describes in terms of man's imperfect finite faculty versus the allknowing perfection of God ${ }^{54}$ becomes man's misery and God's glory. ${ }^{55}$ Descartes' rational speculation is relocated in an emotive sphere. Loyola may have agreed with Pascal on this point.

Pascal's thought is founded on the tripartite structure of the body ordered by nature and custom, the spirit guided by reason, and the heart subject to divine love. ${ }^{56}$ Pascal writes that man must have the three qualities of Pyrrhonism, which makes him doubt when he has to, geometry, which assures him when necessary, and Christianity, to which he submits when he should, and it is the power of reason that tells us when to use each quality. Those who always doubt fail to submit, and

\footnotetext{
${ }^{46}$ Gilson, Études sur le rôle de la pensée médiévale, 35.

${ }^{47}$ Gilson, Études sur le rôle de la pensée médiévale, 29.

${ }^{48}$ Gilson, Études sur le rôle de la pensée médiévale, 28.

${ }^{49}$ Gilson, Études sur le rôle de la pensée médiévale, 30.

${ }^{50}$ Gilson, Études sur le rôle de la pensée médiévale, 49-50.

${ }^{51}$ See his letter to the Sorbonne in Descartes-Lewis, 1.

52 Blaise Pascal, Les Provinciales, Pensées et opuscules divers, ed. Philippe Sellier (Paris: Librarie Générale Française, 2004), 937n2.

${ }^{53}$ Pascal, Les Provinciales, Pensées, 947.

54 Descartes-Lewis, 57.

55 Pascal, Les Provinciales, Pensées, 936.

${ }^{56}$ Pascal, Pascal le cour, 9-11.
} 
those who always submit fail to judge. ${ }^{57}$ Pascal agrees with the Cartesian premise that the intelligence belongs to the intelligible and the body to nature, ${ }^{58}$ but he thinks that Cartesian philosophy does not have the third quality of Christianity that is based on heart. Moreover, Pascal accuses Descartes of stealing his famous "I think therefore I am" from Saint Augustine, who is the central figure for Jansenism. ${ }^{59}$ Pascal also disagrees with Descartes, and for that matter with the Society, on the point of free will that Descartes generously admits as volonte,,${ }^{60} \mathrm{a}$ spontaneous will toward truth. ${ }^{61}$

Keeping these positions in mind, especially the role of free will, we now approach the second point. We cannot talk about the implementation of Christianity in Japan without mentioning Alessandro Valignano, the Jesuit visitor of India and then of Japan. His writing reiterates the incommensurable differences that separate Europe and Japan. The visitor came to Japan three times. His first visit was from July 25, 1579 to February 20, 1582. ${ }^{62}$ The second visit was from 1590 to 1592, and the last and the longest visit lasted from 1598 to $1603 .{ }^{63}$ In his first visit, Valignano determined the grand outline of the mission and steered it in a new direction. The second time, he came back with the Tenshō mission. Among the objects that the four young Japanese on the Tenshō mission brought home from Europe was a printing press that started the Jesuit Mission Press in Japan. During his last visit, the visitor coped with a very uncertain political situation.

The Japan of his time was recovering from wars that split the country for one hundred years, called the Warring States Period, and after the death of the warlord who unified Japan, Oda Nobunaga (1534-82), who was favorable toward the Jesuits, Toyotomi Hideyoshi (1536-98, in office 1585-98) who immediately took power after Nobunaga, was another warlord, less favorable to Christianity. From his death in 1598 to the de facto seizure of power by Tokugawa Ieyasu (in office 1603-5) in 1600 at the Battle of Sekigahara, the situation moved rapidly. Valignano (1539-1606) did not live to see the first edict of proscription of Christianity in 1612. The direction that Valignano chose for Japan was broadly the same strategy that the Society employed in the entire region from India to Japan, namely maintaining the Catholic doctrine stipulated by the Council of Trent in principle and applying it flexibly in practice.

The Japan mission was unique in that elsewhere the Society could always find the rhetoric of doctrinal coexistence with another religion. Catholicism encountered everywhere in the world the problem of idol worship, and the Jesuits' eastward move was no exception. In South Asia, other Catholic orders had started

\footnotetext{
${ }^{57}$ Pascal, Les Provinciales, Pensées, 930.

${ }^{58}$ Pascal, Les Provinciales, Pensées, 946, 951.

${ }^{59}$ Pascal, Les Provinciales, Pensées, 141.

${ }^{60}$ Pascal, Les Provinciales, Pensées, 133-34.

${ }^{61}$ Descartes-Lewis, 57.

${ }^{62}$ Josef Franz Schütte, S.J., Valignano's Mission Principles for Japan, trans. John J. Coyne, S.J., 2 vols. (St. Louis, MO: Institute of Jesuit Sources, 1980), 1:37.

63 Alessandro Valignano, Les jésuites au Japon, Relation missionnaire (1583), trans. Jacques Bésineau, S.J. (Paris: Desclée de Brouwer, 1990), 16.
} 
preaching since the late Middle Ages. ${ }^{64}$ In China, the Jesuit Matteo Ricci interpreted Confucianism as an ethical system, not a religion, that conforms to natural law and is therefore not idolatrous. ${ }^{65}$ In India in 1623, Pope Gregory XV (r.1621-23) gave his approval to Roberto de Nobili, who argued that Brahmanism is a "civil ceremony, not a religious one" with "an ancient core of philosophical truth which might be deemed natural and non-idolatrous." faced a highly organized religion, Buddhism, and the Society could not find the doctrinal rhetoric, during the Christian Century of Japan that lasted from 1549 to 1639, to argue that Buddhism can coexist with Christianity, as it did with Chinese Confucianism and Indian Brahmanism.

The overseas missions, and their art of survival, are ingrained in the Society's modus operandi. Valignano writes in his Sumario (Summary) completed on October 28, 1583 that the young Society is taking shape at the same time as its foreign missions are growing. John W. O'Malley, S.J. writes that in 1549 there were only thirteen Jesuits in Paris against thirty in India, and by 1565 three thousand Jesuits were dispersed in Eastern and Western Europe, India, Japan, Brazil, and other "exotic places." ${ }^{\prime \prime}$ Before its formative period was over in Europe, the Society was already expanding around the world, and this posed a danger. Valignano writes that the Society cannot by any means govern the Japanese church with European legislation; for this young church is developing each day, at the same time as the newly founded Society is developing. ${ }^{68}$ The new church of Japan is placed at the middle of customs so foreign to Europe that "it is a dangerous enterprise in which we may commit serious errors." ${ }^{69}$ Gnecchi-Soldo Organtino, the mission superior of Japan, wrote the following remark: "If [this nation] submits to the faith, my opinion is that no Church in the world will surpass [that of Japan]." "70 This positive opinion balanced a negative one: "Your Paternity may be aware of the gross vices which disfigure their nature." 71 Japanese customs and views are so different that in order to conduct their mission, Valignano advised his companions to exercise extreme caution. ${ }^{72}$

What summarizes Valignano's outlook is his high opinion of Japan and its people, which, however, does not erase the excruciating difficulty of understanding people's minds. Here is the passage that best represents Valignano's judgment:

If we talk about virtue and letters, we cannot see any better natural disposition in other places, for the Japanese are naturally inclined to be the masters of their passions, easy to access, gentle, prudent, and thoughtful,

\footnotetext{
${ }^{64}$ Joan-Pau Rubiés, "Concept of Cultural Dialogue and the Jesuit Method of Accommodation: Between Idolatry and Civilization," Archivum historicum Societatis Iesu 84, no. 147 (January-June 2005): 237-80, here 239.

${ }^{65}$ Rubiés, "Concept of Cultural Dialogue," 246.

${ }^{66}$ Rubiés, "Concept of Cultural Dialogue," 239, 252.

67 John W. O’Malley, The First Jesuits (Cambridge, MA: Harvard University Press, 1993), 51, 54.

${ }^{68}$ Valignano, Les jésuites au Japon, 116.

${ }^{69}$ Valignano, Les jésuites au Japon, 117.

${ }^{70}$ Quoted from his letter of September 29, 1577 in Schütte, Valignano's Mission Principles, 2:105.

${ }^{71}$ Schütte, Valignano's Mission Principles, 2:105.

72 Schütte, Valignano's Mission Principles, 2:168.
} 
remarkably modest and serious, respectful of social conventions, capable of suffering from starvation and cold, hard-trained by pain even when paying its cost with their own person, and that in the same way for the kings, lords, or their subjects; they endure with a lot of patience the loss of their wealth and persecutions, without murmur or complaint, and in all occasions, even in death, they show a great power of soul and a large heart. ${ }^{73}$

Valignano ends this passage with the following remark: "We cannot doubt the help of grace from God our Lord, which already calls them [Japanese] by his grace to his Law, in a manner different from what we see in any other nations in the Orient." 74

However, Valignano also observed that Europeans would never be able to attain "union of heart" with the Japanese on their own: only through its Japanese members could the Society truly reach out to the people and take root in Japanese society. ${ }^{75}$ In a world where there was no modern technology of communication, Europeans and Japanese were invincibly ignorant of each other's way of life. The visitor humbly concludes that in Japan, even wise and knowledgeable Europeans are like children forced to relearn speaking, sitting, walking, and a thousand other things. ${ }^{76}$ Japanese customs and manners are so different from those of Europe and India that fragments of information will not help, and even "those who know well Japan cannot be understood in Europe even by a personal contact, and much less by letters."77 Valignano felt unable to share joys and sorrows with people observing totally outlandish social practices. In other words, the visitor saw the naturally favorable propensities of the people, but he was inhibited by a massive wall of convention behind which these natural inclinations were expressed. Based on this awareness, Valignano's strategy was to educate Japanese ordained priests who could preside in Japanese churches. None of us Europeans, Valignano writes, can learn how to write presentable books in the Japanese language, or how to preach in the language respectably enough to the person of dignity, even to the level of what an ignorant Japanese coadjutor can do. ${ }^{78}$ The only solution is to bring up the Japanese church supported by Japanese Jesuits, and in order to do so, the Society has to advance carefully and slowly.

Thoughts and ideas, either in philosophy, arts, or in religion, should be expressed through a conventional style of language (including images, music, and language proper) with which the people are already familiar. What the Jesuits faced in Japan is the dissociation between expressions and thoughts, whose association was taken for granted in Europe. William Farge, S.J. writes: "The Jesuits were also somewhat inhibited by the European mentality that was not fully aware of the distinction between the content of faith and Christian (i.e., European) culture." 79 It

\footnotetext{
${ }^{73}$ Valignano, Les jésuites au Japon, 172.

74 Valignano, Les jésuites au Japon, 172.

75 Valignano, Les jésuites au Japon, 158.

76 Valignano, Les jésuites au Japon, 81.

77 Valignano, Les jésuites au Japon, 116.

${ }^{78}$ Valignano, Les jésuites au Japon, 167.

${ }^{79}$ William Farge, S.J., The Japanese Translations of the Jesuit Mission Press, 1590-1614, De Imitatione Christi and Guía de Pecadores (Lewiston: Edwin Mellen Press, 2002), 122.
} 
is not only culture but the entire social system extending to political, economic, artistic, and religious spheres that is informing our invisible vision, and these conventional forms of expression have been historically implemented so deeply in people's minds that the border between culture and inner life becomes indistinguishable. The Jesuits had to negotiate this challenge in order to convey their apostolic message.

The Society was compelled to use what it found as the closest conventional form to its religious expression, and so it relied on Buddhism ${ }^{80}$ for the vocabulary of translation, the ritual forms of worship, ${ }^{81}$ and the hierarchical structure of Japanese members ${ }^{82}$ to explain that Christianity is effectively a religion and a respectable one at that. Then they had to insist on their differences with Buddhist belief because, as Jacques Bésineau, S.J. notes, sacrificing Ignatian spirituality is absolutely out of the question, but that spirituality, in order to be well rounded and true to Loyola, needs to be carefully matched with the psychological conditions of a national temper. ${ }^{83}$ Because the gap separating Christian expressions of faith from the local style in Japan was wide and deep, the Society had to improvise a method to stand on the two pillars of uncompromising adherence to Jesuit principles and rhetorical freedom to persuade the population of the truth of its doctrine. The doctrinal principles were presented through publication and education adapted to Japanese culture, while persuasion is a matter of preaching.

Now we start the third point about the rhetoric of persuasion. In contrast to the strict adherence to principle, the rhetoric of persuasion is an art of performance. Japanese art from the latter half of the sixteenth to the beginning of the seventeenth centuries has a special genre that depicts the arrival of Europeans. Called Namban Art or Art of the Southern Barbarians ${ }^{84}$ this genre is divided between secular and religious paintings. On the secular side, the golden screens and the decorative arts produced for Japanese domestic taste as well as for exportation to Europe bear precious witness to the activity of the Society. Bésineau remarks that the artists interpret the sentiment of their public, "of exotic marvels, ironic amusement, realistic familiarity," with a mixture of welcome and curiosity. ${ }^{85}$

These golden screens are painted with a set of cultural and artistic conventions that evolved historically, of which the most marked feature is the golden clouds that separate the pictorial plane into different fragments. This technique, observed already in the scrolls of The Tale of Genji from the beginning of the twelfth century, is a long-standing Japanese visual tradition that allows artists to assemble scenes occurring in different times and places on one pictorial plane. A pair of six-fold screens entitled The Arrival of the Portuguese by Kano Naizen $(1570-1616)$ is one such example that shows a Christian church in which a priest is presiding over Mass.

\footnotetext{
${ }^{80}$ Schütte, Valignano's Mission Principles, 2:276; Valignano, Les jésuites au Japon, 87-88.

${ }^{81}$ Shütte, Valignano's Mission Principles, 2:314.

${ }^{82}$ Terms like dōjuku and kanbō to designate Japanese brothers and service persons are taken from the Buddhist monastery.

${ }^{83}$ Valignano, Les jésuites au Japon, $168 \mathrm{n} 3$.

${ }^{84}$ The Chinese word to designate the Portuguese that Japan adopted.

${ }^{85}$ Valignano, Les jésuites au Japon, 20-21.
} 


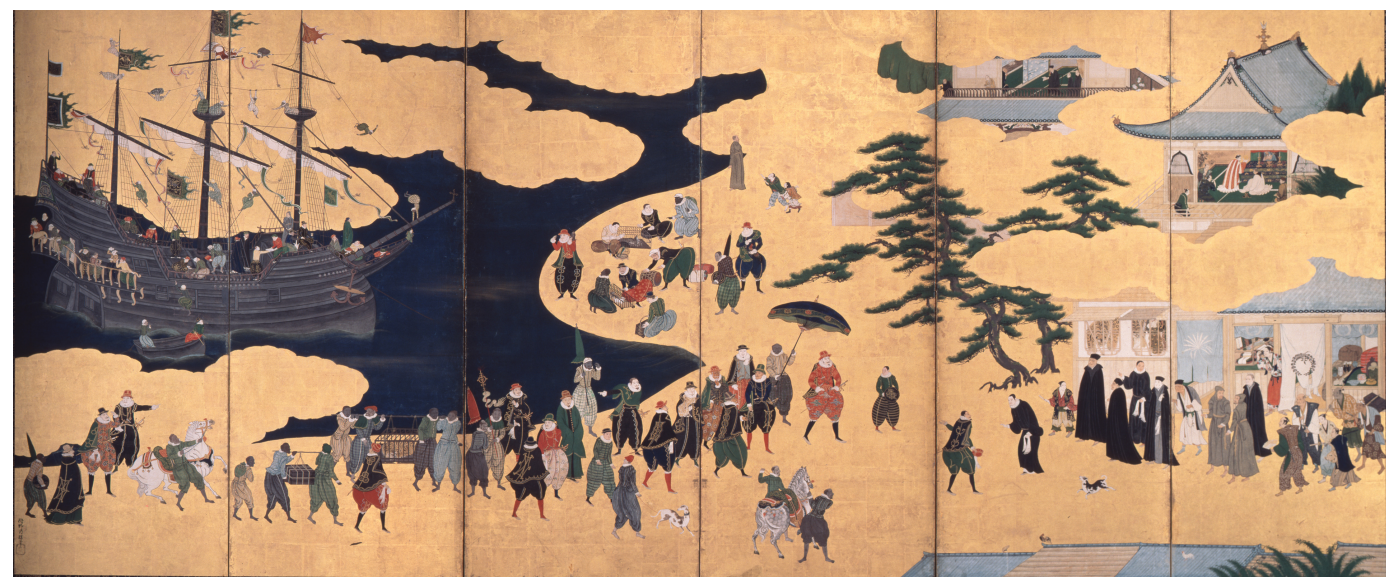

Figure 3. Kanō Naizen, Nanban Byōbu. Right screen. A pair of six-fold screens from the late 16th to the beginning of the 17th C.. Each screen measures $154.5 \times 363.2 \mathrm{~cm}$. Courtesy of Kobe City Museum, Kobe, Japan. Important Cultural Property. The Jesuit church top right has a window open to a veranda, inside which a Jesuit priest wearing a brocade cape in red and white stripes is conducting mass in front of an altar painting that represents Christ holding a cross. A group of Jesuits are walking in front of their church with the members of the mendicant orders. The tall Jesuit who reappears in the left screen that depicts European cityscape is probably Alessandro Valignano, S.J..

In his Advertimentos e avisos acerca dos costumes e catangues de Jappão (Warnings and notices about the costumes and customs of Japan) of 1581, ${ }^{86}$ Valignano defines many detailed principles on church architecture and its interior. After the description of living quarters, kitchen, pantry, guest rooms, a tearoom to entertain guests according to Japanese custom, and community rooms for quiet study, the visitor describes, as the eighth and ninth rubrics, the church and its choir where the altar is placed for the Mass. ${ }^{87}$

The church that the visitor describes is a Japanese structure that is not recognizable as a church if we do not see a cross on the roof. The open floor plan of the church is like a Buddhist temple, but the Christian altar of worship is placed deeper and farther away from the entrance, while the Buddhist altar is placed in front of the open veranda of the room. ${ }^{88}$ The visitor also stipulates that it is a "reasonable adaptation to have on the right and left of the choir, after the Japanese pattern, special zashiki (sitting rooms)" for those whose ranks are too high to be seated with the general worshippers. ${ }^{89}$ Gauvin Alexander Bailey points out that "three-aisled floor plans" are common features adopted not only by the Jesuits but also by Franciscans and Dominicans in altar plans of foreign missions, and this Japanese floor plan "coincidentally evoked the three-aisled basilicas of the Early

\footnotetext{
${ }^{86}$ Schütte, Valignano's Mission Principles, 2:155n24.

${ }^{87}$ Schütte, Valignano's Mission Principles, 1:187-89.

${ }^{88}$ Schütte, Valignano's Mission Principles, 1:189.

${ }^{89}$ Schütte, Valignano's Mission Principles, 1:189.
} 
Church." 90 Bailey pays attention to the Jesuit term noster modus (our mode) applied to all architecture in foreign missions and wonders if this tripartite floor plan of Japanese churches that looks so Buddhist is not also noster modus of the Jesuits. ${ }^{91}$

If we return to Naizen's screen, the artist observed well the European fathers, dressed in black cassock and hat, and recorded their figures and church architectures in his painting. Naizen's works are reputed for their realism. Ethnographic details of clothing, an admiral's whistle, the sword hilt, a curbed knuckle-bow, the way to carry a sword or hang it from the belt, have been collated with contemporary European customs and authenticated. ${ }^{92}$ Naizen traveled to Nagasaki when he was twenty-two years old in 1593 after he finished decorative paintings in Hideyoshi's castle, and he sketched European customs and people after the real models in his screen. Takamizawa Tadao also speculates that Naizen may have actually attended Christian ceremonies, like the Mass that he depicts here. In the painting, the altar is made of black lacquer, and a devotional painting is hung at its center. What is intriguing is the priest's ceremonial costume: he is wearing bright bold stripes of red and white. Since it is not European and certainly not Buddhist, where did it come from? Obviously the Jesuits in Japan took some liberty in the interpretation of their ceremonial chasubles.

One point of contention among Society members from the early period of their mission in Japan is the silk costume. Francisco Cabral, S.J., who directed the early stage of the Jesuit mission as the superior of Japan, "deployed all his energy and authority in getting rid of the silk kimono as Jesuit dress." 93 The silk garment was worn by the Buddhist clergy, and the Jesuits did not want to look like them. Besides, the Jesuits should respect their religious principle of frugality. In accordance with the uniformity of dress among the Jesuits, they should wear all black with the "black skullcap (barrette)" 94 except Japanese-style socks that can be blue or chestnut brown. How about "the long Jesuit mantle" 95 that they wear in Europe? Some Jesuits including Cabral thought that they should get rid of that, too. Some others thought that they should wear this European Jesuit mantle "on festive occasions when visiting distinguished people, for example, New Year's Day." 96 Later, the strict disciplinarian attitude of Cabral made Organtino, whose tolerant attitude constituted the opposite pole, write a letter saying that as long as Cabral remains the superior of Japan, "no progress could be hoped for in these kingdoms." 97

The visitor Valignano, who sought a middle ground between Cabral and Organtino, did not change much in Cabral's direction on the matter of clothing. In the Advertimentos (1581) that he added in order to set the first method of adaptation

\footnotetext{
${ }^{90}$ Gauvin Alexander Bailey, Art of the Jesuit Missions in Asia and Latin America, 1542-1773 (Toronto: University of Toronto Press, 1999), 44, 64.

${ }^{91}$ Bailey, Art of the Jesuit Missions, 43, 64.

92 Takamizawa Tadao, "Commentary to Fig. 70-73," in Nihon byōbu shūsei, ed. Sakamoto Mitsuru et al. (Tokyo: Kōdansha, 1979), 15:109-10.

93 Schütte, Valignano's Mission Principles, 2:43.

${ }^{94}$ Schütte, Valignano's Mission Principles, 2:44.

95 Schütte, Valignano's Mission Principles, 2:44.

96 Schütte, Valignano's Mission Principles, 2:44.

${ }^{97}$ Schütte, Valignano's Mission Principles, 2:97.
} 
in Japan, Valignano redefines Jesuit clothing in minute detail, and this provision is not only set down as a principle but also put into practice. Valignano maintains the earlier prohibition of wearing silk and advocates the Jesuit uniform patterned in agreement with Indian and European costume, in other words, a black soutane with a round black hat. ${ }^{98}$ What interests us here is the rule set by Valignano for the ceremonial mantle, "to be worn only on great feast days or on formal visits, especially those paid to distinguished people, particularly if they were pagan." 99 The Jesuits followed the rules, and whenever necessary, they took freedom by reading between the lines of their rules. That is why they wore a very colorful ceremonial mantle in the Mass.

In countries where the local languages were not easy to master, the Jesuit mission relied on visual impact. The Jesuits brought Jerónimo Nadal's Evangelicae historiae imagines (Illustrations of the Gospel stories), which has 153 engraved images, ${ }^{100}$ and an atelier of painters founded by Giovanni Niccolò formed painters for European devotional painting from 1583 to $1614 .{ }^{101}$ The left half of the six-fold screen painted by Naizen illustrates well how the Europeans and Japanese of this period were distant not only in artistic conventions of expressions but also in their mutual knowledge of towns and buildings. This left half of the screen depicts a European cityscape that would be unrecognizable to Europeans. So we understand today how difficult it was to imagine Europe even for one of the best-informed painters of the Christian century of Japan.

${ }^{98}$ Schütte, Valignano's Mission Principles, 2:245.

99 Schütte, Valignano's Mission Principles, 2:245.

${ }^{100}$ Fernando García Gutiérrez, S.J., "Valignano and the Introduction of Western Art in Japan," in Alessandro Valignano S.I. (Rome: Institutum Historicum Societatis Iesu, 2008), 175-83, here 176.

${ }^{101}$ Hui-Hung Chen, "Seminary of Painters in Japan," in The Cambridge Encyclopedia of the Jesuits, ed. Thomas Worcester, S.J. (Cambridge: Cambridge University Press, 2017), 734; Bailey, Art of the Jesuit Missions, 66-72. 


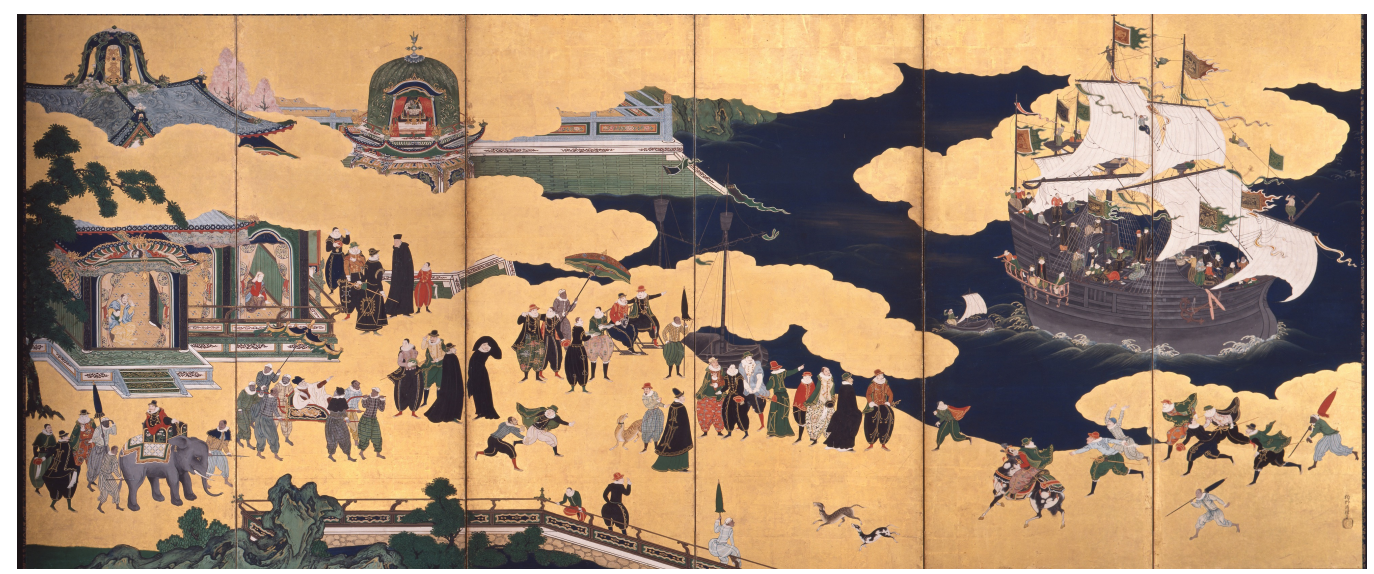

Figure 4. Kanō Naizen, Nanban Byōbu. Left screen A pair of six-fold screens from the late 16 th to the beginning of the 17th C. Each screen measures $154.5 \times 363.2 \mathrm{~cm}$. Courtesy Kobe City Museum, Kobe, Japan. Important Cultural Property. European cityscape with a church marked by a cross on the domed roof, at the top left corner of the screen. Kanō Naizen was one of the best-informed Japanese painters about European costumes and customs through his familiarity with the activity of the Society of Jesus. His difficulty to imagine the European cityscape makes us see today a wide cultural gap between Europe and Japan in the $16^{\text {th }} \mathrm{C}$. The exchange of visual arts was an important means employed by the Society to bridge that gap.

European religious paintings, engravings, and church rituals were helpful, but in order to display the orthodox Catholic doctrine more effectively, the Jesuits complied with the local values and artistic customs. In their records, the two Jesuits Luís Fróis and João Rodrigues mention that lacquerware is everywhere in Japan. In his Historia de igreja do Japão (History of the church in Japan), the author Rodrigues, habitually called Rodrigues the interpreter (Rodrigues Tçuzu), writes that the "art of varnishing" is practiced "throughout the whole kingdom" to coat tableware, tables, and trays as well as the scabbards of swords and daggers, handles of lances, and sheathes of blades. ${ }^{102}$ Rodrigues continues in the same entry that among the countries where the same trees are found to extract the raw material of varnish, China, Vietnam, Cambodia, and Thailand, "Japanese stand supreme in this art," and the varnish makes the wood smooth like ivory and hard like glazed clay. He concludes that it is the most common decorative art in the Japan of his time.

Fróis writes in his History of Japan that lacquer is a part of the Japanese state decorum used ostentatiously to demonstrate sumptuousness and luxury. In Japan, true lacquerware still has the status of Western sterling silver today. Fróis describes how Toyotomi Hideyoshi, who followed Oda Nobunaga and ruled over a unified Japan, rode in a carriage lacquered in polished black with the wheels coated with lacquer shining like a mirror. ${ }^{103}$ The Jesuits, too, used lacquer in the Japanese way to show their dignity to the Japanese public. According to Fróis, when

\footnotetext{
102 João Rodrigues, Nihon kyōkaishi, trans. Ikegami Mineo et al. (Tokyo: Iwanami Shoten, 1970), 2:56-58; João Rodrigues, João Rodrigues's Account of Sixteenth-Century Japan, ed. Michael Cooper (London: Hakluyt Society, 2001), 326-27.

${ }^{103}$ Luís Fróis, Nihon shi, trans. Matsuda Kiichi and Kawasaki Tōta (Tokyo: Chūōkōronsha, 1977), 2:29; Fróis, Kan'yaku Fróis Nihonshi, trans. Matsuda Kiichi and Kawasaki Tōta (Tokyo: Chūōkōronsha, 2018), 5:31.
} 
Gaspar Vilela, S.J. presided over a funeral for a pious Japanese Christian of high rank, he wore a brocade mantle and rode in a carriage lacquered in red. ${ }^{104} \mathrm{~A}$ large number of Japanese Christians followed Vilela, some wearing a short or a long white cassock, and some had the idea of throwing the altar cover obliquely from one shoulder in imitation of Buddhist kesa. In order to make the funeral procession more sumptuous and splendid, the file was guided by a large cross, followed by those who carried candles, the Bible with a ceremonial cover, holy water bowl, the altar picture of Christ, and many silk standards with the picture of the mystery of the passion. The Jesuits and Japanese Christians took everything from their church, and they marched solemnly for about four kilometers. Fróis writes that there were ten thousand spectators, and at the cemetery Japanese Christians sung in Latin in a beautiful accent to the utter amazement of spectators. ${ }^{105}$ It was an improvised performance, more impressive than a mantle in red and white stripes or an altar in lacquer.

Now, we approach our concluding part. Makoto Harris Takano writes that the primary purpose of Jesuit theatrical and musical performances is "to move the soul." 106 If the soul is moved, it will choose to be converted with a free will. A free will is a freedom to obey the divine will, and that is supported by a trust in the infallibility of God's grace. ${ }^{107}$ Valignano appreciates that "Japanese become Christians of their own free will." 108 In his respect of free will, we hear a Jesuit speaking, and on this point of free will, we return to Europe to conclude.

Its mission may have brought its members to the four corners of the world, but the Society was always under the governance of the Holy See and under the superior general's supervision. Back in Japan, Valignano and his companions made an effort to be in agreement with the papacy in a country where everything is so deeply opposite of Europe ${ }^{109}$ and where a majority practiced Buddhism and Shintoism. The visitor wrote:

There are so many difficulties in the governance of this Christendom that we cannot decide matters according to the writings of the doctors, but we are always forced to decide hic et nunc. We need to receive a wide margin of freedom in jurisdiction and the power to dispense many cases; for, if treated in each detail, these cases will pose in Rome great difficulties. ${ }^{110}$

When Japanese cases of conscience concerning idol worship worried him, Valignano sent questions to European universities in Alcala, Salamanca, Coimbra,

\footnotetext{
${ }^{104}$ Fróis, Kan'yaku Fróis Nihonshi, 1:311.

105 Fróis, Kan'yaku Fróis Nihonshi, 313.

${ }^{106}$ Makoto Harris Takano, “'In what storms of blood from Christ's flock is Japan swimming?' Gratia Hosokawa and the Performative Representation of Japanese Martyrdom in Mulier fortis (1698)," in Changing Hearts, Performing Jesuit Emotions between Europe, Asia, and the Americas, ed. Yasmin Haskell and Raphaële Garrod (Leiden: Brill, 2019), 87-113, here 112.

${ }^{107}$ Hans R. Guggisberg et al., La liberté de conscience (XVI-XVIIe siècles) Actes du Colloque de Mulhouse et Bâle (1989) (Geneva: Droz, 1991), 18.

108 Valignano, Les jésuites au Japon, 109n2. O’Malley, First Jesuits, 61.

109 Valignano, Les jésuites au Japon, 117.

110 Valignano, Les jésuites au Japon, 118.
} 
and Evora to be discussed by scholars, and their answers were reviewed in the Congregation of the Cardinals and approved by Pope Clement VIII (r.1592-1605). The casuistic specifically adapted for Japan was then sent with a letter of the superior general of the Society Claudio Acquaviva (in office 1581-1615) to Valignano, who received it in Macao in April 1597, and this papal approval reached Japan around 1598. ${ }^{111}$ The influence in China of the pope's approval for Japanese is a further subject of study. The same also applies to the relationship between the aforementioned Advertimentos e avisos, ${ }^{112}$ which Josef Franz Schütte introduces as "the Book of Ceremonies" in Japan, ${ }^{113}$ and Il cerimoniale per $i$ missionari del Giappone (The ceremonial for the missionaries of Japan), which was used in China, ${ }^{114}$ China being a part of the Japanese province until 1615 and its actual separation being delayed until $1623 .{ }^{115}$

One case that Valignano sent to the theologians in European universities in 1592 was the following. Can a Japanese Christian accompany his master to the Buddhist temple in a situation where he would face death for disobeying his master? ${ }^{116}$ Depending on the theologians, the details vary, but the outline of guidance stipulates that Japanese Christians can do all deeds necessary for their smooth social and professional life provided that they do not worship idols. ${ }^{117}$ This local variation of cases was deployed on the theological ground of Thomism. In France, this practice of casuistic founded on the notion of invincible ignorance in moral theology became the subject of intense attacks aimed at the Society in the seventeenth century. The case of the Japanese servant working for his Buddhist master looked absurd in France when translated to the French context of a relationship between the Christian servant and his Christian master. The Jesuits in Europe failed to engage the sources and explain that this case was originally fitted for Japanese customs. Valignano petitioned Rome for papal approval in order to guarantee the survival of Christianity in a foreign land.

Jean-Pascal Gay demonstrates that the reference to Suárez in the text of François Jacops, S.J., who defended the French variation of servant-master relationship, was erased in the censorship conducted by Guy de Sève de Rochechouart in the 1670s. ${ }^{118}$ Suárez contributed to the Jesuit casuistic through the theological revival of Thomism. When Valignano submitted his inquiry about the Japanese cases of conscience, one theologian who responded in 1595 was Gabriel Vázquez. ${ }^{119}$ Like Suárez, Vázquez belonged to the most moderate, classical

\footnotetext{
${ }^{111}$ Asami Masakazu, Kirishitan jidai no gūzōsūhai (Tokyo: Tokyo Daigaku Shuppankai, 2009), 148.

${ }^{112}$ Schütte, Valignano's Mission Principles, 2:197, 376.

${ }^{113}$ Schütte, Valignano's Mission Principles, 2:155-90, here 162.

${ }^{114}$ Michela Catto, "The Generalate of Claudio Acquaviva: The Origins of the Jesuit Myth of China," in The Acquaviva Project: Claudio Acquaviva's Generalate (1581-1615) and the Emergence of Modern Catholicism, ed. Flavio Rurale and Pierre-Antoine Fabre (Chestnut Hill, MA: Institute of Jesuit Sources, 2017), 129-47, here 129; Asami, Kirishitan jidai no gūzōsūhai, 294.

${ }^{115}$ Catto, "Generalate of Claudio Acquaviva," 132 and 132n17.

${ }_{116}$ Asami, Kirishitan jidai no gūzōsūhai, 152-53.

${ }^{117}$ Asami, Kirishitan jidai no gūzōsūhai, 140-72.

118 Jean-Pascal Gay, Morales en conflit: Théologie et polémique au Grand Siècle (1640-1700) (Paris: Les Editions du Cerf, 2011), 305-8.

119 Asami, Kirishitan jidai no gūzōsūhai, 148.
} 
casuistic tradition, ${ }^{120}$ and both were active in Spain after Charles V (r.1519-56), who governed a transmarine empire. Suárez volunteered for a foreign mission, ${ }^{121}$ and we thus know that he was familiar with the geographical scope of Jesuit missions. His vision is reflected in his work on international law and the notion of the community of nations. Sometimes called the Second Scholastics, Vázquez and Suárez are often situated in the "autumn of the Middle Ages." 122 This view may obscure the cultural shifts that transformed the notion of invincible ignorance after these Jesuit theologians from the end of the sixteenth to the beginning of the seventeenth century revived it from Saint Thomas Aquinas.

Vásquez, Suárez, and the Jesuit theologians of their generation followed the Jesuit Constitutions. The Constitutions of the Society of Jesus open with the "Formulas Approved and Confirmed by Pope Paul III and Julius III" that state the absolute obedience of Jesuits to the papal order of missions in the following terms: "We pledge to do this whether he [the pope] sends us among the Turks or to other infidels, even to the land they call India." 123 In 1540, two years before the discovery of Japan by three Portuguese sailors, India also included all lands to the east of the Ganges River. In Japan, where Xavier reported to Europe that there was no knowledge of Christianity, the notion of invincible ignorance was applicable to the whole population in absolute terms. In a society where Christians were an overwhelming minority even after the Jesuit mission, it was an urgent necessity to establish clear and concrete examples of cases of conscience to protect Japanese Christians and the Jesuits who were administering the sacraments so that they would not commit the sin of idol worship. Idol worship is a theme in the domain of moral theology, but in the province of India, this question was treated as a case of conscience, with many sample cases occurring under concrete circumstances, ${ }^{124}$ for use in the manual of sacraments of absolution for those who were guiding the local Christians in a non-Christian environment. ${ }^{125}$

Gay offers a careful and detailed analysis of the redactions of the Ratio studiorum and remarks that casuistic appears in the Ratio from an essentially practical perspective. ${ }^{126}$ This redaction of the Ratio was advanced during the period when Valignano was actively proctoring the province of India and exchanging letters with Acquaviva. More research is necessary to support the relationship between Acquaviva's emphasis on casuistic in Jesuit institutions and Valignano's reports and his inquiry about cases of conscience in India. In Europe, Jesuits worked at the forefront of the Counter-Reformation to suppress heresy. This situation must be one reason for Acquaviva's emphasis on cases. On the other hand, Schütte emphasizes the warm friendship between Valignano and Acquaviva that shines

\footnotetext{
${ }^{120}$ Gay, Morales en conflit, 652.

${ }^{121}$ William V. Bangert, S.J., A History of the Society of Jesus (St. Louis, MO: Institute of Jesuit Sources, 1986), 186.

122 Bangert, History of the Society of Jesus, 114.

123 John Padberg, S.J., ed., The Constitutions of the Society of Jesus and Their Complementary Norms (St. Louis, MO: Institute of Jesuit Sources, 1996), 7.

${ }^{124}$ Asami, Kirishitan jidai no gūzōsūhai, 140-43.

125 Asami, Kirishitan jidai no gūzōsūhai, 168.

126 Gay, Morales en conflit, 529.
} 
through their letters. ${ }^{127}$ The extent of topics covered by the exchange between Valignano and Acquaviva was truly wide and diverse, and that conversation lasted for a quarter of a century ${ }^{128}$ during the burgeoning period of the Society when Acquaviva was pursuing the completion of the Constitutions and the Ratio studiorum and the administrative reorganization of the Society's educational system. During the time when Acquaviva was in office, invincible ignorance became the notion of moral theology that enabled the strategic application of cases in the practical grounds of missions in and out of Europe. That this notion became one of the most criticized points of the Society's moral theology in France brings us back to Pascal to conclude. ${ }^{129}$

Unlike questions of practice, when the pope promulgates his decision on the level of theological principle, that decision binds all Catholics in the world, including the Society. About fifty years after Valignano obtained the papal seal of approval on the level of Japanese practice, in France religious tolerance was the subject of dispute on the matter of different interpretations of Augustinian grace. This controversy, usually thought of as a European controversy, intensified with the publication of Augustinus written by Cornelius Jansen in 1640, and censured by Pope Urban VIII (r.1623-44) in 1642. We need to put the Jansenist polemic with the Society in the global context of Jesuit missions. This Jansenist criticism is summarized in seven propositions, the first five of which became particularly controversial. ${ }^{130}$ Pascal challenged Molinism, the name given to the followers of Spanish Jesuit Luis de Molina's book entitled De concordia liberi arbitrii cum divince gratice donis (About the union of free will with the gifts of divine graces [1588]), and more immediately the Liber theologice moralis (Book of moral theology) written by the Spanish Jesuit Antonio Escobar, whom Pascal quotes most heavily in his Lettres provinciales (Provincial letters). ${ }^{131}$

Called "le docteur de la grâce" (the doctor of grace), ${ }^{132}$ Saint Augustine's notion of divine grace was interpreted by Jansenists in a very rigid way, so much so that their idea of predestined grace called efficacious grace gave Port-Royal, the citadel of Jansenism, a reputation for Calvinism. ${ }^{133}$ In this very French Catholic debate of theology about divine grace surrounding Pascal's Provinciales, Pascal overlooks the historical fact that the Jesuit definition of grace was tightly related to their overseas missions. With the Jansenist definition of grace, it is impossible to undertake any mission in a non-Christian foreign land where no population can claim to be predestined, not only to divine grace but also to Christianity.

The controversy is whether God decided human salvation before or after Adam's fall. The Calvinists think that God chose those who would be saved before

\footnotetext{
${ }^{127}$ Schütte, Valignano's Mission Principles, 1:9.

${ }^{128}$ Schütte, Valignano's Mission Principles, 1:363.

${ }^{129}$ Gay, Morales en conflit, 324.

${ }^{130}$ Louis Cognet, "'Les Provinciales' et l'histoire," in Pascal, Les Provinciales, Pensées, 157-229, here 167.

${ }^{131}$ Cognet, “'Les Provinciales' et l'histoire,” 158, 191-92.

${ }^{132}$ Pascal, Les Provinciales, Pensées, 293 and 293n1; Cognet, “'Les Provinciales' et l'histoire," 157.

${ }^{133}$ Pascal, Les Provinciales, Pensées, 291.
} 
the fall of Adam, and Adam fell because he was not chosen. ${ }^{134}$ The Catholic Church thinks that the source of salvation is in God's will whereas the source of damnation is in man's will. ${ }^{135}$ Descartes essentially adheres to this position by switching it to the question of good and bad judgments. ${ }^{136}$ Jansenists and Jesuits both agree that God's grace was given to all men without exception in Eden, but after Adam's fall, the Jesuit and Jansenist positions diverge. The Jesuits think that by the merit of Christ, God gives grace to all men, and it depends on each individual to choose it with his own will. ${ }^{137}$ The Jansenists admit the Jesuit position only for man in Eden. ${ }^{138}$ The Jansenists think that God's grace is not given to all after Adam's fall, but God did not disclose whom he chose; therefore man must live in anguish to see if God gave him a gift of persevering in virtue, which is also predestined by God. ${ }^{139}$ If a man fails to persevere, he then discovers that he is in fact predestined to fall.

The eighteen letters of Pascal's Provinciales, written from January 23, 1656 to April 1657, coincide with the period when the Society, having retreated from Japan in 1639, was advancing in China. France under Louis XIV (r.1643-1715) was also sponsoring overseas missions involving Jesuit scientists. The Holy See, at the time when Pascal was writing the Provinciales, had to strike a precarious balance between, on the one hand, its Asian and American missions that required a maximum tolerance and, on the other, the domestic situation in Europe, where a call for stricter discipline was rising from Jansen and others. In the midst of the vivid polemic of Pascal's Provinciales that spread the theological problem to lay readers thanks to his fine and persuasive style, ${ }^{140}$ Pope Alexander VII (r.1655-67) issued a bull on October 16, 1656 that was officially handed to the French king Louis XIV on March 11, 1657. The bull said that the pope acknowledges Jansen's authorship of the five propositions and he condemns them. ${ }^{141}$ On September 6, 1657, Pascal's Provinciales were put on the Index. ${ }^{142}$

Pascal refutes the Jesuit premise that "all infidels have God's sufficient help, always and everywhere," which Jansenists felt was an insult to the singular grace of Christ, who did not give his forgiveness to all. ${ }^{143}$ In the Pensées (Thoughts), where he talks about the miserable situation of "Turks, heretics, and infidels" who follow their fathers' ways, Pascal says, "It is for that reason the savages do not know what to do with Providence." "144 To this passage, Philippe Sellier puts a note that refers to Montaigne who inspired Pascal with the following passage: "It is through the intervention of custom that each individual is happy with

\footnotetext{
134 Blaise Pascal, "Écrits sur la grâce," ed. Michel le Guern in Euvres complètes II (Paris: Gallimard, 2000), 209-316, here 259.

135 Pascal, "Écrits sur la grâce," 310.

${ }^{136}$ Descartes, Meditationes de prima philosophia, Méditations métaphysiques, 60.

${ }^{137}$ Pascal, "Écrits sur la grâce," 260, 308.

138 Pascal, "Écrits sur la grâce," 261.

139 Pascal, "Écrits sur la grâce," 262-63.

${ }^{140}$ Gérard Ferreyrolles, "'Les Provinciales' et la littérature," in Pascal, Les Provinciales, Pensées, 230, 248-50; Laurent Susini, "Pascal écrivain," in Blaise Pascal, Pascal le cour et la raison, ed. Jean-Marc Chatelain (Paris: Bibliothèque Nationale de France, 2016), 99-106, here 99, 103-4.

${ }^{141}$ Cognet, "“Les Provinciales' et 1'histoire," 207.

${ }^{142}$ Cognet, “'Les Provinciales' et 1'histoire," 211.

143 Pascal, "Écrits sur la grâce," 314.

144 Pascal, Les Provinciales, Pensées, 939.
} 
the place where nature planted him, and the savages in Scotland do not know what to do in Touraine." ${ }^{45}$ The Jesuits in Japan believed that foreign customs could be turned away from their original purpose as rhetorical instruments so that they could persuade people to freely choose their faith in their native environment. With this, we conclude that the Society's strongest arm of persuasion in foreign missions is its respect for the free will to choose God's grace that it acknowledged in all people of all social venues and nations, no matter what customs they practice.

${ }^{145}$ Pascal, Les Provinciales, Pensées, 939n1. 